OPEN ACCESS

Edited by:

Juan José Dorantes-Aranda, Institute for Marine and Antarctic

Studies (IMAS), Australia

Reviewed by:

Matthew John Harke,

Columbia University, United States

Sai Elangovan S.,

National Institute

of Oceanography (CSIR), India

*Correspondence: David U. Hernández-Becerril dhernand@cmarl.unam.mx

Specialty section: This article was submitted to Marine Ecosystem Ecology, a section of the journal

Frontiers in Marine Science

Received: 03 July 2018 Accepted: 24 September 2018

Published: 12 October 2018

Citation:

Hernández-Becerril DU, Lau WLS, Hii KS, Leaw CP, Varona-Cordero $F$

and Lim PT (2018) Abundance and Distribution of the Potentially

Toxic Thecate Dinoflagellate

Alexandrium tamiyavanichii (Dinophyceae) in the Central Mexican

Pacific, Using the Quantitative PCR Method. Front. Mar. Sci. 5:366. doi: 10.3389/fmars.2018.00366

\section{Abundance and Distribution of the Potentially Toxic Thecate Dinoflagellate Alexandrium tamiyavanichii (Dinophyceae) in the Central Mexican Pacific, Using the Quantitative PCR Method}

\author{
David U. Hernández-Becerril1*, Winnie L. S. Lau², Kieng S. Hii², Chui P. Leaw², \\ F. Varona-Cordero' ${ }^{1}$ and Po T. Lim² \\ 1 Instituto de Ciencias del Mar y Limnología, Universidad Nacional Autónoma de México, Ciudad de México, Mexico, \\ ${ }^{2}$ Institute of Ocean and Earth Sciences, University of Malaya, Kuala Lumpur, Malaysia
}

Most of the toxic algal blooms in coasts of the Mexican Pacific are attributed to planktonic dinoflagellates. Recently, some new records of dinoflagellates producers of emergent toxins have been documented. The genus Alexandrium encompasses several toxic species which produce saxitoxin. In this work, the abundance and distribution of the potentially toxic species Alexandrium tamiyavanichii from coasts of the central Mexican Pacific were studied, following the method of quantitative real-time PCR. During the oceanographic cruise "MareaR IX" (19-30 April, 2017), carried out along coasts of the Mexican Pacific, hydrographic, and environmental variables were measured, and net and bottle samples were collected and preserved in modified saline ethanol buffer for analysis in the laboratory. In order to perform the qPCR method, the molecular target used was the ITS2 of the rDNA of $A$. tamiyavanichii. From 45 samples analyzed, 14 yielded positive results, showing the presence and abundance of the species in fixed stations of Cabo Corrientes, Manzanillo and Acapulco, with low densities (less than $40 \mathrm{cell} s / \mathrm{m}^{3}$ ), which is an evidence of the sensitiveness of the method. On the other hand, chains of cells of the species were found in net samples, in stations where its presence was detected by qPCR, confirming results by the method. General distribution showed presence of the species in two zones where upwellings were detected, but not at coastal stations, except in Acapulco where a more stratified water column was found. Vertical distribution indicated that highest densities were found at subsurface layers, in association with the chlorophyll a maxima (between 11 and $30 \mathrm{~m}$ depth). The results show the importance of assessing the abundance and distribution of a species which may be systematically monitored, and that the method of the qPCR may be very useful.

Keywords: Alexandrium tamiyavanichii, central Mexican Pacific, dinoflagellates, molecular tools, quantitative real time PCR 


\section{INTRODUCTION}

The Mexican Pacific is a very large region which comprises various different areas with particular climatic and oceanographic conditions, including more temperate zones (e.g., western coasts of Baja California) and subtropical and tropical zones (e.g., the Gulf of California, the central Mexican Pacific and the Gulf of Tehuantepec) (Fiedler and Lavín, 2006). The phytoplankton composition may therefore be different within certain areas and zones, and also during different seasons. The central Mexican Pacific is considered a tropical region, which may also be divided according to its hydrographic and oceanographic characteristics as well as its seasonality (Kessler, 2006). In the zone of Cabo Corrientes, upwellings have been detected to occur by spring, whereas more to the south, other zones (e.g., close to Acapulco and surroundings) show more stable conditions, with a more stratified water column (Willett et al., 2006; Zamudio et al., 2007).

Harmful algae blooms (HABs) have been historically recorded along the coasts of the Mexican Pacific, most of these events being caused by planktonic dinoflagellates, for which responsible species have been usually well-recognized, the most commonly recorded are Gymnodinium catenatum and Pyrodinium bahamense (Hernández-Becerril et al., 2007), whereas other dinoflagellate species considered harmful or producing "emergent toxins" (for example Azaspiracid toxins or Pinnatoxins) have been recently identified: Azadinium spinosum and Vulcanodinium rugosum, although they have not been reported to produce blooms or toxins as yet (Hernández-Becerril et al., 2012, 2013).

Within the phytoplankton, one of the most important genera with species known to form blooms and produce toxins [mainly saxitoxins, which cause the Paralytic Shellfish Poisoning (PSP)] is the thecate dinoflagellate genus Alexandrium Halim. A number of works have reported blooms, toxin production, human intoxications, economic losses in many places around the world (e.g., Hashimoto et al., 2002; Beppu et al., 2008; Kon et al., 2015; Mohammad-Noor et al., 2018). In the Mexican Pacific the genus is represented by several species (Okolodkov and Gárate-Lizárraga, 2006), some of them responsible for producing blooms or toxins elsewhere. However, the species identification has been a problem and little is known about the distribution of toxic Alexandrium species in the central Mexican Pacific, apart from coastal areas. Alexandrium tamiyavanichii was described forming long chains (chains of 62 cells have been found), with a particularly shaped first apical $\left(1^{\prime}\right)$ and anterior sulcal plates (Sa), and a conspicuous and large pore at the posterior sulcal plate (Sp), besides the apical pore complex (Po) (Balech, 1995), and it is considered a toxic species producing saxitoxin and other toxins. This species has been previously found and described in the central Mexican Pacific (Esqueda-Lara and Hernández-Becerril, 2010).

However, observation of these cells under microscope is tedious, time-consuming and requires trained personnel in phytoplankton identification (Cembella and Taylor, 1986; Steidinger and Moestrup, 1990). Therefore, systematic and rapid manners are needed to provide more accurate information on the potentially toxic phytoplankton species by using the advent of molecular tools. Molecular-based species-specific assays, such as the quantitative real-time PCR (qPCR), have proven to be a reliable and rapid method for assessing and monitoring the abundance and distribution of toxic phytoplankton species, especially those of problematic identification, as those belonging to the genus Alexandrium (Lim et al., 2007). For instance, qPCR has been developed and implemented to study the distribution of A. tamiyavanichii in the South China Sea-Sulu Sea (Kon et al., 2015). Through this assay, it was found that A. tamiyavanichii is highly abundant offshore of Kuching, southern Borneo with 150 cells $\mathrm{L}^{-1}$ (Kon et al., 2015).

In qPCR assays, a pair of good primers is important to amplify the targeted DNA region. It enables amplification of the targeted DNA region with no other unintended target regions (Ye et al., 2012). The qPCR primer is usually designed with an amplicon size of less than 150 bp (Arya et al., 2005; Arvidsson et al., 2008; Ye et al., 2012). Other criteria in primer region are: 18-30 nucleotide length, GC content of 40-60\%, more than one mismatches to non-target DNA or organism, melting temperature of forward and reverse primer should be similar or within $2^{\circ} \mathrm{C}$ and improbable with formation of primer dimer or heterodimer (Arya et al., 2005; Ye et al., 2012). On the other hand, slope of the calibration curve used for absolute quantification qPCR is in the range of -3.1 to -3.6 , with the amplification efficiency (AE) of $90-110 \%$ and the $\mathrm{R}^{2}$ greater than 0.99 .

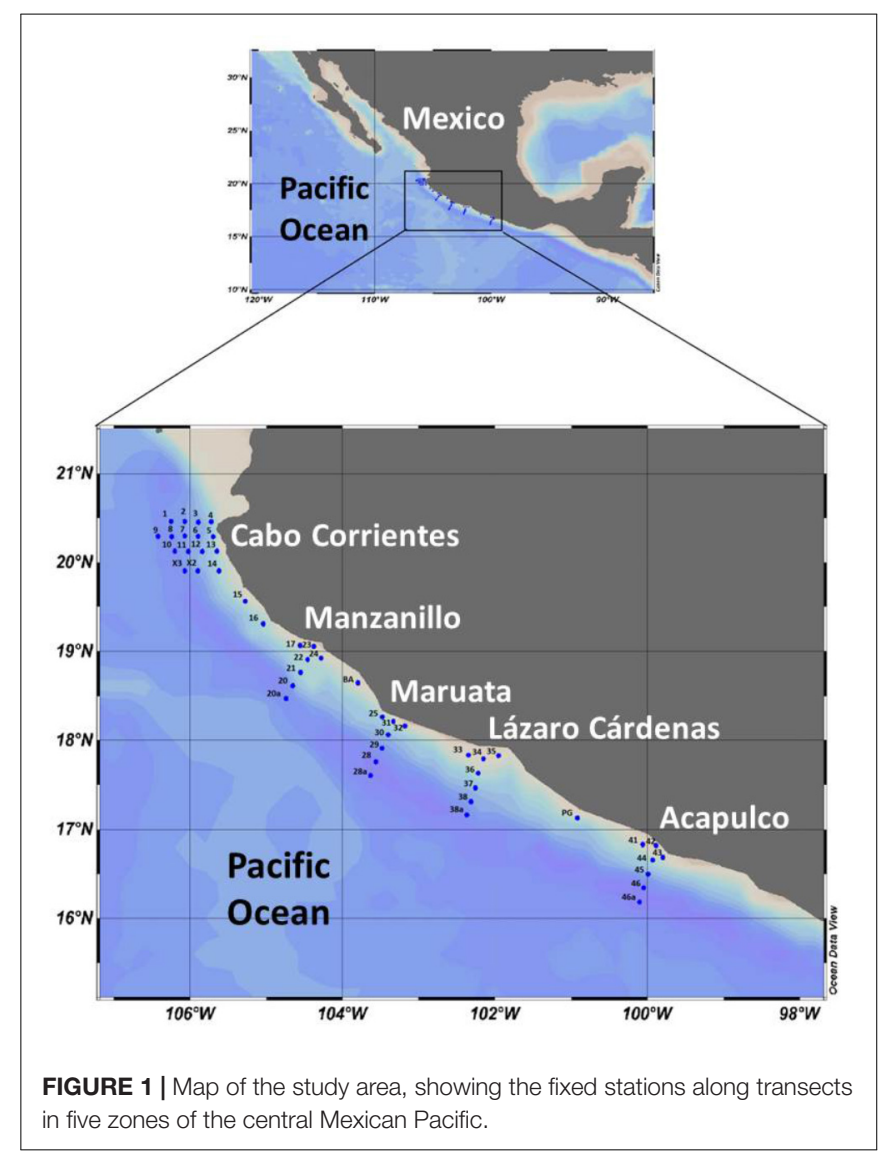


A Temperature $\left({ }^{\circ} \mathrm{C}\right)$

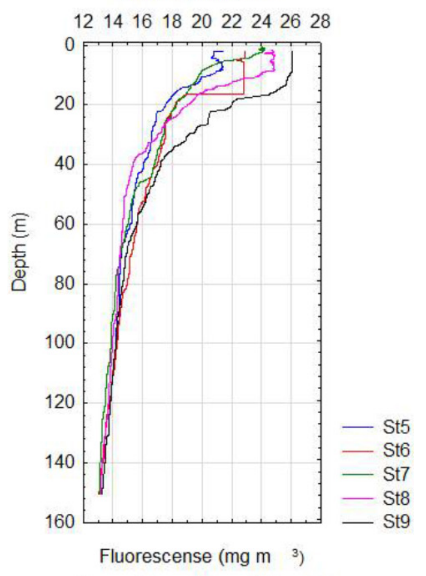

C
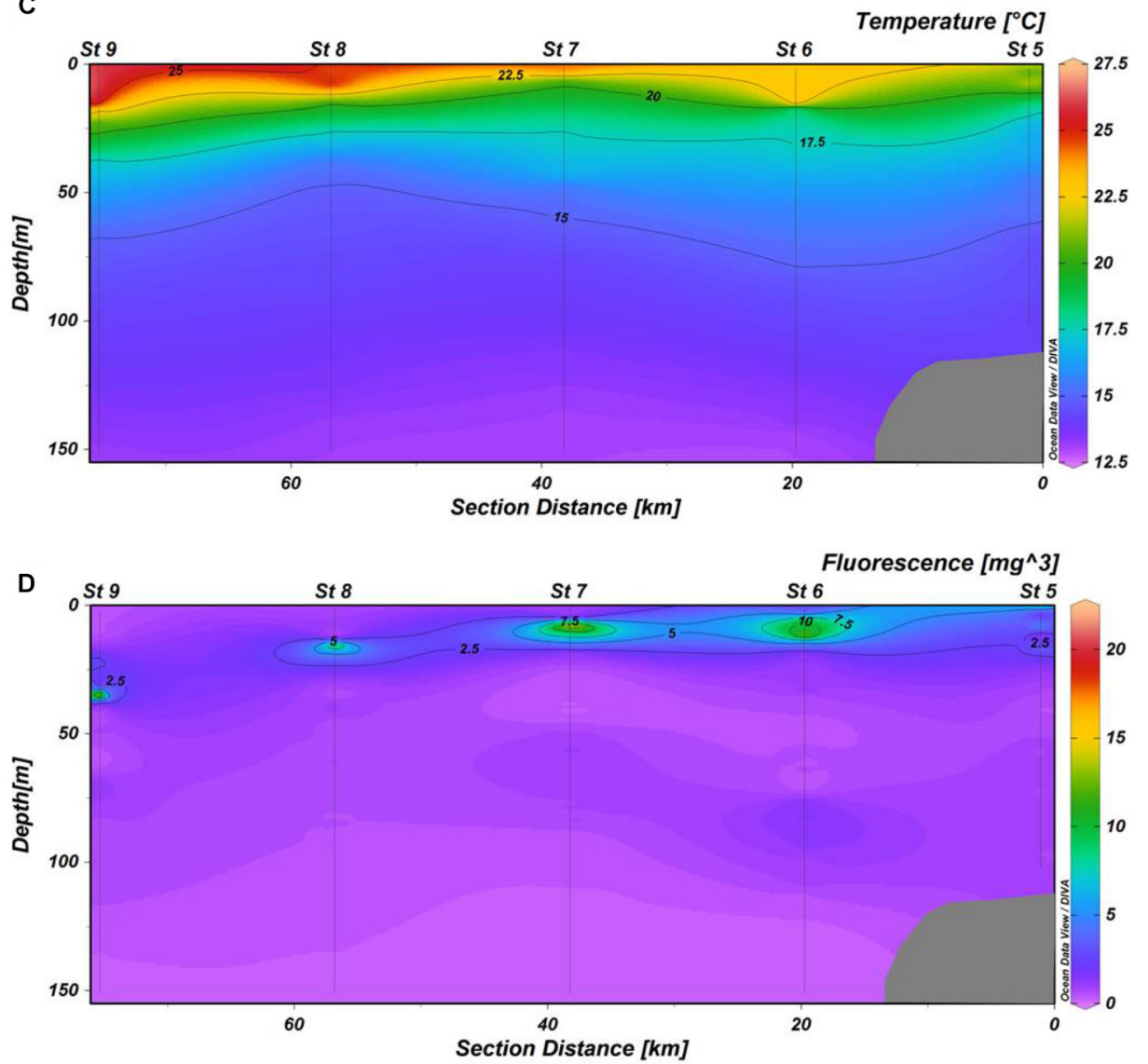

D

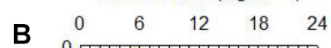

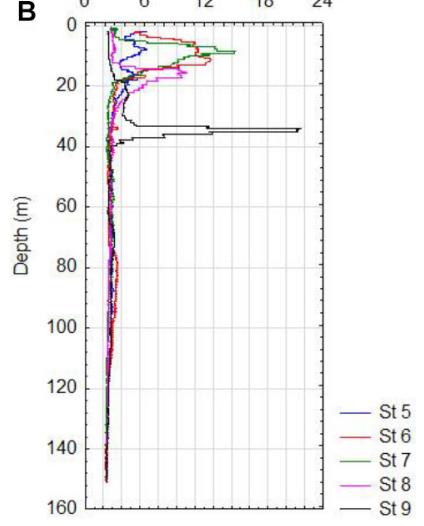

FIGURE 2 | (A,B) Vertical profiles of temperature and in situ fluorescence for stations 5-9 of the transect in Cabo Corrientes, respectively. (C,D) Maps of the distribution of temperature and in situ fluorescence for stations 5-9 in Cabo Corrientes, respectively.

In this paper, we give an account of the abundance and distribution of the toxic thecate dinoflagellate A. tamiyavanichii from the central Mexican Pacific using a real-time quantitative PCR (qPCR) assay.

\section{MATERIALS AND METHODS}

\section{Study Area}

This study was conducted in an area of the central tropical Mexican Pacific, between $16^{\circ} 20.421$ and $20^{\circ} 27.500 \mathrm{~N}$, and $100^{\circ} 02.922$ and $106^{\circ} 15.052 \mathrm{~W}$ (Figure 1). This area sustains a great diversity of organisms and important pelagic fisheries, with different mechanisms of natural fertilization such as mesoscale phenomena (plumes and eddies) and upwellings, and shallow thermoclines reducing stratification and keeping relatively high phytoplankton biomass values (López-Sandoval et al., 2009). The area is located within an oxygen minimum zone (Paulmier and Ruiz-Pino, 2009; Ulloa et al., 2012), and some hydrographic features might affect the vertical distribution of biological properties such as chlorophyll $a$.
Data and samples were measured and collected during the oceanographic cruise "MareaR IX," carried out 19-30 April, 2017, on board the Research Vessel "El Puma," considering five zones: Cabo Corrientes (stations 1-14, X2, X3), Manzanillo (stations 17, 20a-24), Maruata (stations 25, 28a-32), Lázaro Cárdenas (stations 33-38a), and Acapulco (stations 41-46a) (Figure 1). There are additional intermediate stations $(15,16, \mathrm{BA}$, and PG), but only stations in perpendicular transects were sampled (5-9, 20a-23, 28a-31, 34-38a, 42-46a) (Figure 1).

\section{Hydrographic Data and Water Sampling}

Forty-one fixed stations were visited during the cruise (Figure 1) to obtain hydrographic data (temperature, salinity, dissolved oxygen) in vertical profiles, using a CTD (Seabird SBE 911 PLUS), fitted with an additional sensor for fluorescence (WET Labs ECOAFL/FL), and water samples. Transects perpendicular to the coastline of five stations were set for each of the five zones (Figure 1). For this study, water samples were collected with Niskin bottles of $10 \mathrm{~L}$, from nine stations, at five depths, according to the in situ fluorescence (chlorophyll a) maximum layers or peaks: $1 \mathrm{~L}$ per sample was filtered through nylon membrane filters (47 mm diameter, $0.2 \mu \mathrm{m}$ ) filters with a vacuum pump. 
A Temperature $\left({ }^{\circ} \mathrm{C}\right)$

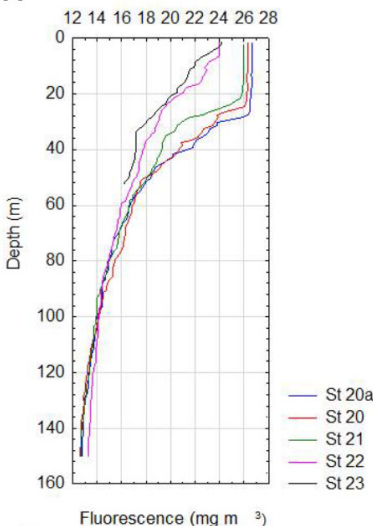

B $\left.1 \mathrm{~m}^{2}\right)$
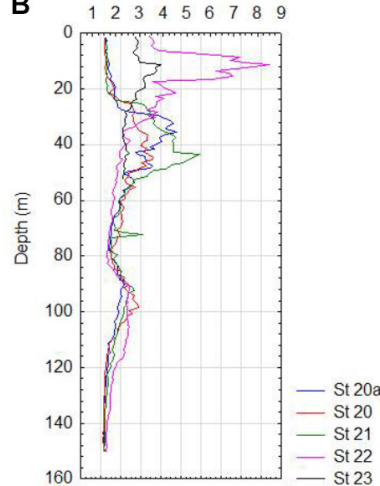

C

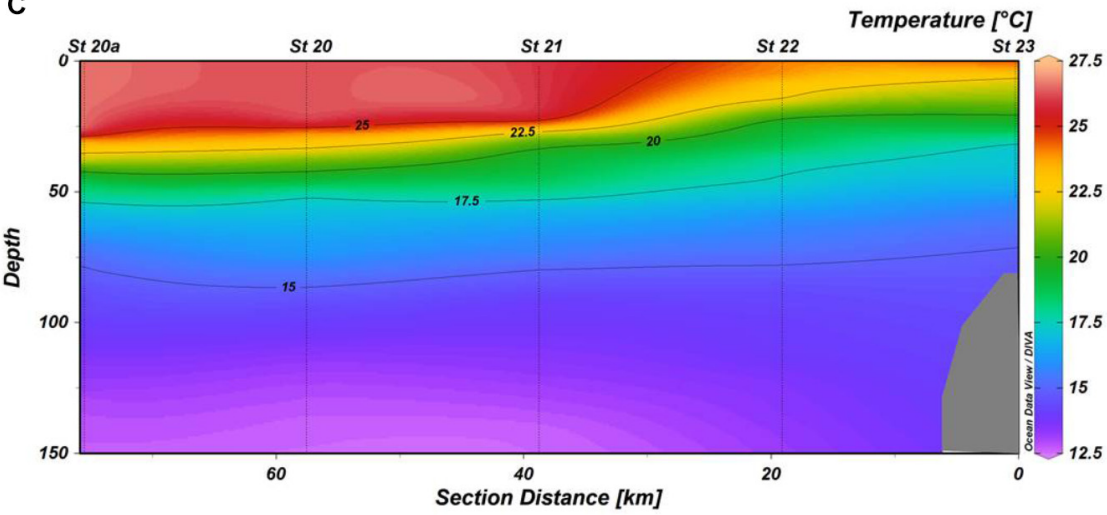

D

Section Distance [km]

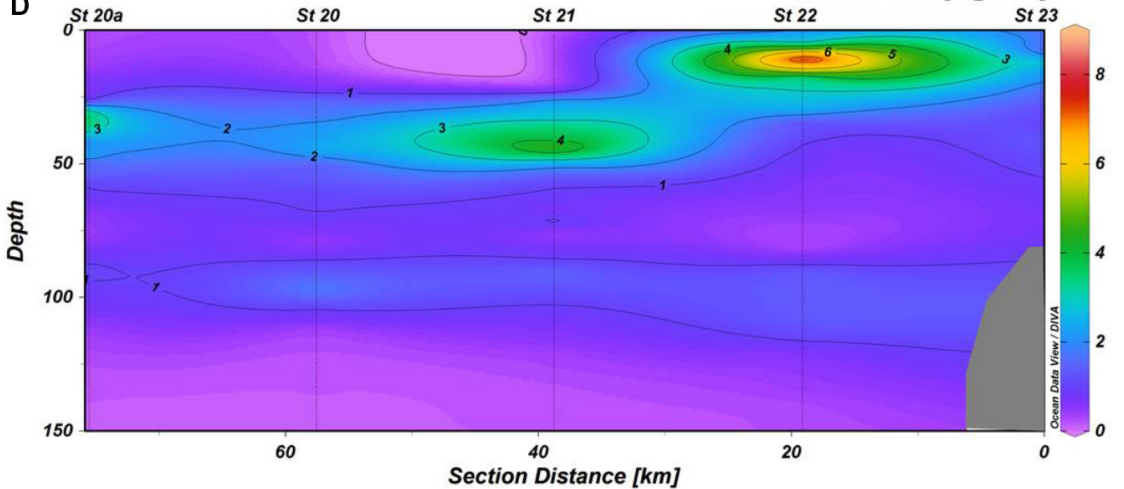

FIGURE 3 | (A,B) Vertical profiles of temperature and in situ fluorescence 20a-23 of the transect in Manzanillo, respectively. (C,D) Maps of the distribution of temperature and in situ fluorescence $20 \mathrm{a}-23$ in Manzanillo, respectively.

Each filter was kept in $10 \mathrm{~mL}$ of modified saline ethanol solution into a $15 \mathrm{~mL}$ sterile centrifuge tubes and stored at $-20^{\circ} \mathrm{C}$ until analysis (Miller and Scholin, 1998). Additionally, net (54 $\mu \mathrm{m}$ mesh) samples were obtained at all 41 stations, following vertical hauls from $120 \mathrm{~m}$ to surface or depending on the depth of the stations. The net samples were observed under the microscope.

\section{Laboratory Analysis \\ Environment DNA Extraction}

One milliliter of saline ethanol-preserved samples was transferred into $1.5 \mathrm{~mL}$ centrifuge tube and harvested the cells pellet by centrifugation $(200 \times g, 10 \mathrm{~min})$, followed the removal of the saline ethanol supernatant from the cell pellet. The cell pellet was rinsed with $1 \mathrm{~mL}$ of TE buffer (Tris $1 \mathrm{M}$, EDTA $0.5 \mathrm{M}$, pH $8)$ and cells were spun again $(200 \times g, 10 \mathrm{~min})$. Environmental DNA (eDNA) of the samples was extracted by using DNeasy ${ }^{\oplus}$ Plant Mini Kit (Qiagen, Hilden, Germany) according to the manufacturer's instruction as described in Kon et al. (2015). The eDNAs were kept at $-20^{\circ} \mathrm{C}$ until further analysis.

\section{qPCR Assay for Alexandrium tamiyavanichii Cell Quantification}

Real-time quantitative PCR (qPCR) assay of A. tamiyavanichii quantification of Kon et al. (2015) was employed in this study for the detection and quantification of A. tamiyavanichii. Prior to qPCR, specificity of the species-specific primers and probe (TamiaiiF, TamiaiiR, and Tamia-probe; Kon et al., 2015) were confirmed by DNA sequencing of the amplicons.

The qPCR assay was performed using an Applied Biosystems ${ }^{\circledR}$ 7500 Fast Real-time PCR system (Applied Biosystems, Life Technologies, Austin, TX, United States). The $20 \mu \mathrm{L}$-reactions contained $1 \times$ Taqman $^{\circledR}$ Fast Advanced Master Mix (Applied Biosystems), $200 \mathrm{nM}$ of Taqman ${ }^{\circledR}$ hydrolysis probe, $300 \mathrm{nM}$ of each forward and reverse primer and $2 \mu \mathrm{L}$ of eDNA template. The reaction consisted of a holding stage at $50^{\circ} \mathrm{C}$ for $2 \mathrm{~min}$ and $95^{\circ} \mathrm{C}$ for $20 \mathrm{~s}$, followed by 40 cycles of $95^{\circ} \mathrm{C}$ for $3 \mathrm{~s}$ and $60^{\circ} \mathrm{C}$ for $30 \mathrm{~s}$. All samples were run in triplicate. Each qPCR run included a notemplate control and a positive control. The threshold cycle $\left(\mathrm{C}_{\mathrm{q}}\right)$ was determined from the exponential phase of all amplification plots using the default settings. qPCR in this study was conformed to the MIQE guidelines (Minimum Information for Publication of qPCR Experiments; Bustin et al., 2009).

The calibration curve of DNA in this study was constructed using the gBlock $^{\circledR}$ synthetic gene fragment (Integrated DNA Technologies, Coralville, IA, United States) of the ITS2 rDNA of A tamiyavanichii. The synthetic gene fragment was diluted into a 10 -fold serial dilution $\left(1 \times 10^{2}-10^{8}\right.$ copies $)$ as templates in $\mathrm{qPCR}$ run. Each reaction was performed in triplicate. The calibration curve was constructed based on the triplicate $\mathrm{Cq}$ values against the log-transformed copy numbers; linear 


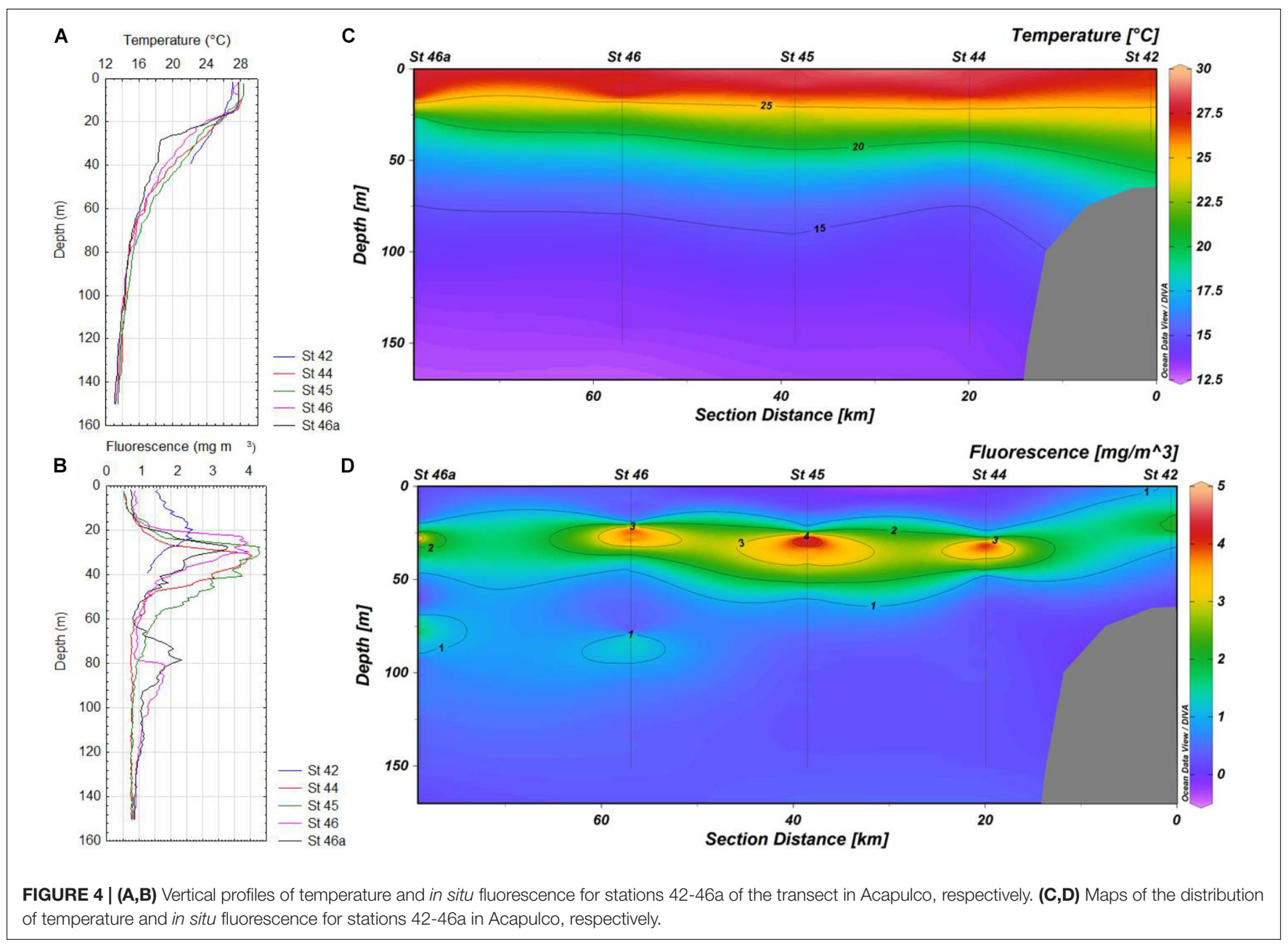

regression was performed onto the calibration curve to determine the $\mathrm{R}^{2}$ value and slope. $\mathrm{AE}$ was calculated as $\mathrm{AE}=\left[10^{(-1 / \text { slope })}\right.$ $-1] \times 100 \%$.

Gene copies number of the A. tamiyavanichii ITS2 rDNA in each eDNA sample was defined based on the slope of simple linear regression of the calibration curve, followed by quantification of the number of cells based on the ITS2 copy numbers per A. tamiyavanichii cell of 527,835 \pm 7617 ITS2 copies cell $^{-1}$ as described in Kon et al. (2015).

\section{Microscopic Identification}

Microscopic species identification was made by calcoflour white staining on the thecal plates of dinoflagellates and observed under an inverted microscope (Olympus IX51, Tokyo, Japan), equipped with a mercury lamp and a UV filter set, at 4001000X magnification. Species identification was confirmed once the distinctive morphological features of A. tamiyavanichii were observed, and microphotographs were taken of the cells and chains found in the samples. These features include an oblique posterior margin of the first apical plate $\left(1^{\prime}\right)$, a triangular to trapezoid-shaped of precingular part of the anterior sulcal plate (Sa), a characteristic apical pore complex (Po), and a longer than wide posterior sulcal plate (Sp) with a large pore.

\section{Data Analysis}

Sampling map and graphic interpolations were generated using Ocean Data View (version 4.7.10) with the DIVA algorithm for variable resolution in a rectangular grid (Schlitzer, 2016). Vertical profiles of environmental variables were made with the STATISTICA 10 software (StatSoft, Inc.) and principal component analysis (PCA), using abiotic and biotic data (abundances and fluorescence) as quantitative variables and transect name as qualitative supplementary variables, was made with XLSTAT 2018.5 (Base version, Addinsoft).

\section{RESULTS}

\section{Hydrography and Oceanographic Conditions}

In April, 2017, general hydrographical conditions along the Pacific coast showed a conspicuous thermal gradient from the north zone (Cabo Corrientes) toward south zones (Acapulco). Surface water was colder (about $21.3^{\circ} \mathrm{C}$ ) in the coastal station (St 5) in Cabo Corrientes, than at the coastal station (St 42) in Manzanillo, where temperature reached $27.5^{\circ} \mathrm{C}$ (Figures 2A,C, 


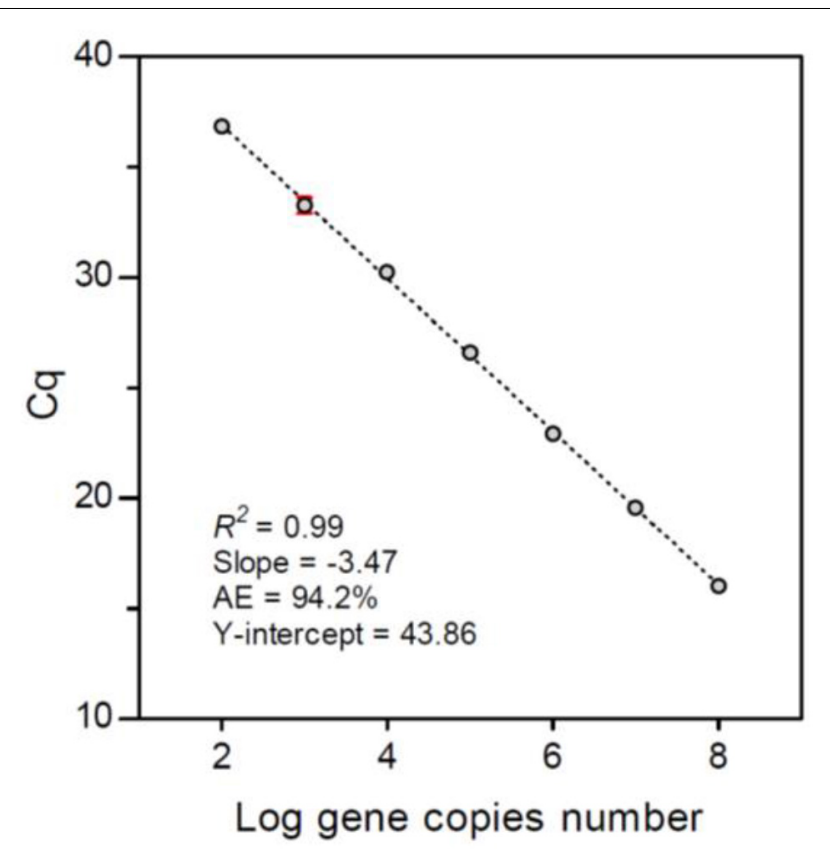

FIGURE 5 | Calibration curve of the cycle threshold (Cq) constructed using the synthetic gene fragment of Alexandrium tamiyavanichii ITS2 rDNA. Error bars show the standard deviations from the triplicate amplifications.

3A,C). We also noted shallower thermoclines in Cabo Corrientes, where they were located below $20 \mathrm{~m}$ depth, whereas thermoclines were deeper (up to $30 \mathrm{~m}$ ) in Manzanillo and Acapulco (Figures 3A,C, 4A,C). Values and distribution of salinity did not change considerably and they are not shown.

Most subsurface fluorescence (chlorophyll $a$ ) maxima (SCM) were located above the main thermoclines in the zone of Cabo Corrientes, except at the most oceanic station (St 9), where this layer was detected lower (37 $\mathrm{m}$ depth), with very high values (more than $20 \mathrm{mg} \mathrm{m}^{-3}$ ), probably as result of a coastal upwelling (Figures 2B,D), whereas in the other zones (Manzanillo and Acapulco) only two stations (St 22 and 23) showed SCM above the main thermoclines, as they were located below the thermoclines (Figures 3B,D, 4B,D). Values of the chlorophyll $a$ in the coastal areas were less than $4 \mathrm{mg} \mathrm{m}^{-3}$.

Deeper (80-90 m depth) chlorophyll $a$ maxima (DCM) were also found at stations 6 and 9 , but due to the scales used they are not very conspicuous (Figures 2B,D). Vertical distribution of chlorophyll $a$ was more variable in Manzanillo, where SCM were located above the thermoclines at the most inshore stations (Sts 22 and 23), whereas the rest of stations (21, 20, and 20a) these maxima were found lower (30-48 $\mathrm{m}$ depth), with the highest concentration at station 21 (more than $6 \mathrm{mg} \mathrm{m}^{-3}$ ) (Figures 3B,D). At station 42 (Acapulco) only a SCM was found, located at $20 \mathrm{~m}$ depth (Figures 4B,D). DCM were also detected in almost all stations, except coastal stations, from 90 to $120 \mathrm{~m}$ depth, and concentrations just lower than $2 \mathrm{mg} \mathrm{m}^{-3}$ (Figures 2D, 3D, 4B,D).

Oceanographic conditions of the zones where A. tamiyavanichii was detected, indicated a conspicuous ascent of colder water toward inshore locations (St 5 in Cabo Corrientes and St 23 in Manzanillo), which was more evident in Cabo Corrientes than in Manzanillo (Figures 2C, 3C), whereas in the Acapulco zone, the coastal station (St 42) showed a more stratified condition (with the main thermocline located at $26 \mathrm{~m}$ depth) (Figures $4 \mathrm{~A}, \mathrm{C}$ ). The isotherms of $22.5^{\circ} \mathrm{C}$ raised close to coast in the zones of Cabo Corrientes and Manzanillo, strongly suggesting the occurrence of upwellings (Figures 2C, 3C).

\section{Alexandrium tamiyavanichii Abundance and Distribution}

The linear dynamic range of seven-order magnitudes $\left(10^{2}-10^{8}\right.$ copies) showed $\mathrm{AE}$ of $94.2 \%$ and slope of $-3.47\left(R^{2}=0.99\right)$, Y-intercept was 43.86 (Figure 5). We have obtained 45 samples for this study, from which only 14 yielded positive results, at two stations in Cabo Corrientes, two in Manzanillo and one in Acapulco, with cell densities ranging from 35 to 25,180 cells $\mathrm{m}^{-3}$ (Figures 6A-C and Table 1). Alexandrium tamiyavanichii cell densities were low in general (less than 30 cells $\mathrm{L}^{-1}$ ) (Table 1 ). Overall cells abundance of $A$. tamiyavanichii increased in the order of Cabo Corrientes, St $7>$ Manzanillo, St $22>$ Acapulco, St $42>$ Manzanillo, St $23>$ Cabo Corrientes St 8 (Table 1). The higher abundances $\left(25,180\right.$ cells $\left.\mathrm{m}^{-3}\right)$ of $A$. tamiyavanichii were located at an intermediate, more oceanic station (which has more than $2000 \mathrm{~m}$ depth), not in a coastal area, at St 7 in the Cabo Corrientes zone.

Regarding the vertical distribution of the species, we detected a maximum abundance layer associated with the SCM (about $15 \mathrm{~m}$ ) in Cabo Corrientes, with a cell density of 25,180 cells $\mathrm{m}^{-3}$ (Table 1), whereas in Manzanillo the maximum cell density was found close to the surface ( $5 \mathrm{~m}$ depth), and the lowest cell densities were detected at Acapulco, St 42 with the depth of $18 \mathrm{~m}$ (35 cells $\mathrm{m}^{-3}$ ) (Figures 6A-C and Table 1). Cells of $A$. tamiyavanichii were detected as deep as $150 \mathrm{~m}$ depth (40.61 cells $\mathrm{m}^{-3}$ ) only at St 7, Cabo Corrientes (Table 1).

Additionally, cells of A. tamiyavanichii were also identified in one of the positive result sample. The cells have also been confirmed with light microscopy (LM) and fluorescence microscopy, with the addition of calcofluor (Figures 7A-C). This fact has confirmed the reliability of the results obtained from the qPCR assay in this study.

\section{Statistical Analysis}

In accordance with the PCA, temperature, depth, salinity and dissolved oxygen explained $94.14 \%$ of the variability (Figure 8). Temperature and oxygen correlated positively with the first component and negatively with salinity and upwelling index which reflects the influence of cold water, while the second axis correlated positively with the upwelling index. Fluorescence and A. tamiyavanichi abundances correlated positively with the first components which suggest its preference for warmer waters and more light. Due to the influence of temperature and dissolved oxygen, samples from Manzanillo and Acapulco were closer than Cabo Corrientes. 


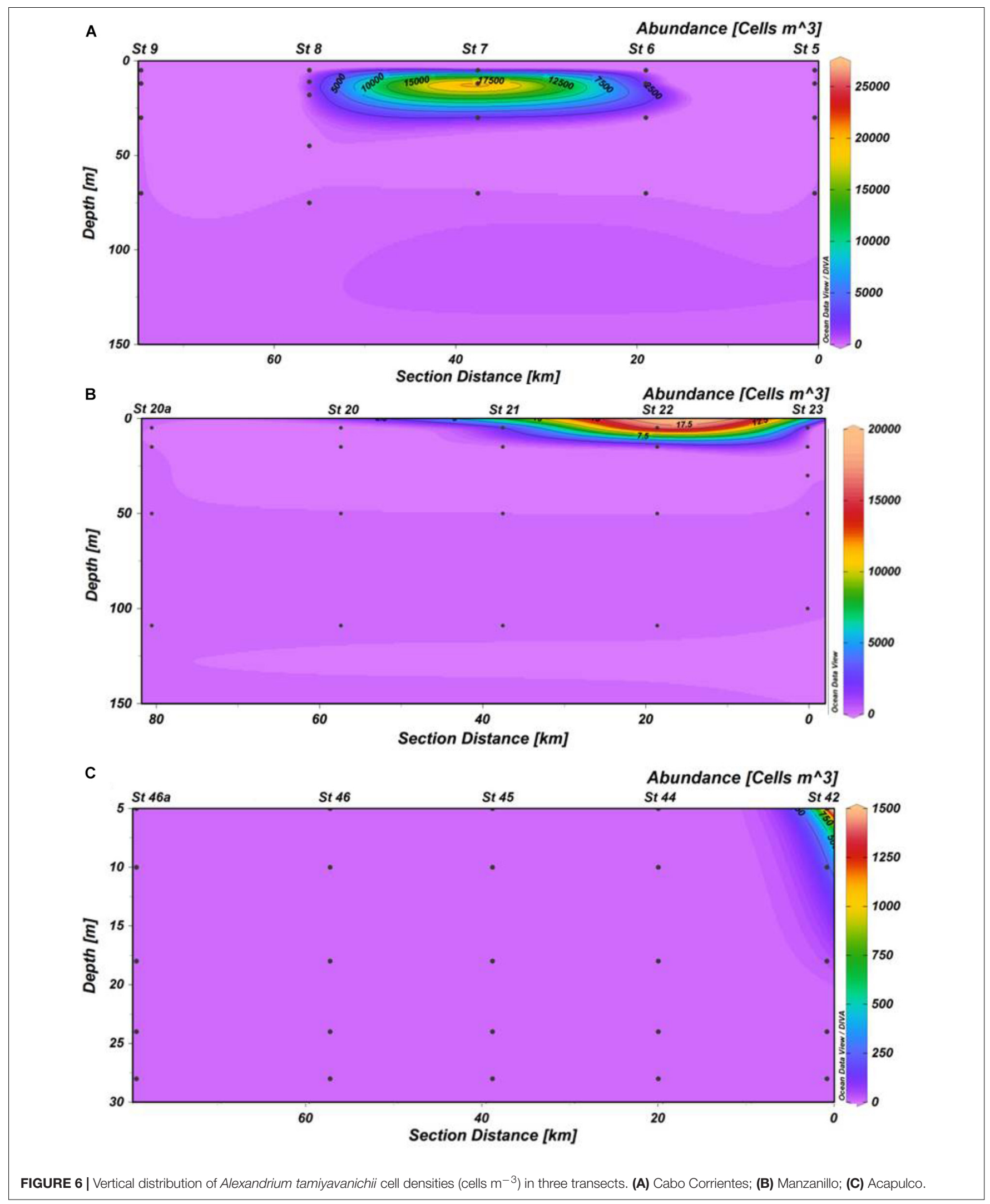




\section{DISCUSSION}

Due to the importance of species of the genus Alexandrium producing toxins in the marine phytoplankton, the diversity and taxonomy of the genus has been dealt with by various authors (Ogata et al., 1990; Balech, 1995; Usup et al., 2002a,b; Mackenzie et al., 2004; Nguyen and Larsen, 2004; Lim et al., 2007), and several works have followed the use of molecular tools to assess the Alexandrium species presence and distribution around the world oceans (Scholin et al., 1994, 1995; Galluzzi et al., 2004; Menezes et al., 2010; Nagai, 2011; Kon et al., 2015).

This is the first report of the abundance and distribution of A. tamiyavanichii in the Mexican Pacific, as well as the use of qPCR to asses these characteristics. We were able to detect cell densities of the species as low as less than 30 cells $\mathrm{L}^{-1}$. The highest abundance $\left(25,180\right.$ cells $\left.\mathrm{m}^{-3}\right)$ of $A$. tamiyavanichii was located at an intermediate, fairly oceanic station (St 7, which is more than $2000 \mathrm{~m}$ deep), coinciding with the SCM (12 $\mathrm{m}$ depth), in the Cabo Corrientes zone, not in more coastal stations, such as it occurred in the other two zones, Manzanillo and Acapulco, where the species was present in detectable cell densities at more coastal areas, close to the surface. Only in that sample (St 7, at $12 \mathrm{~m}$ depth) was the limit of A. tamiyavanichii cell density (2040 cells $\mathrm{L}^{-1}$ ) surpassed, where toxin (saxitoxin) concentration, causing PSP, represents a threat for human health for shellfish consumption (García et al., 2004).

There is a considerable variation in abundances of $A$. tamiyavanichii among the three transects (e.g., Cabo Corrientes, Manzanillo, and Acapulco), showing a heterogeneous distribution in the gradient coast to ocean, and also in the vertical distribution (Figures 6A-C). No cells were detected in the remote stations from the coast, mostly oceanic, in all the three transects (e.g., offshore, such as St 9, 20a, and 46a) (Figures 6A-C). The highest density of the species coincided with the subsurface chlorophyll maximum layer in St 7, in Cabo Corrientes zone (Figures 2B,D, 6A and Table 1), and also a considerable number of cells $\left(19,218\right.$ cells $\left.\mathrm{m}^{-3}\right)$ of $A$. tamiyavanichii was found close to the surface ( $5 \mathrm{~m}$ depth) at St 22, in Manzanillo, almost coinciding with the subsurface chlorophyll maximum layer (between 5 and $10 \mathrm{~m}$ depth) (Figures 3B,D, 6B and Table 1). In St 42 (Acapulco) there was no coincidence of the highest density of the species and the SCM (Figures 4B,D, 6C).

We may speculate that the distribution of the species corresponds to two possible explanations: (1) the cells of $A$. tamiyavanichii were transported off the coast, far from the coastal area, by physical forcing, for in this zone (Cabo Corrientes) an upwelling was detected, most possibly induced by winds, or (2) the species was able to maintain high cell densities in environmental conditions (e.g., a more stratified water column) which were more favorable for its ecological requirements, because in the other stations where the species was detected, the oceanographic conditions were more stable along the water column.

To explain the first hypothesis, we found that prior to the start of sampling in Cabo Corrientes an intense period of upwelling occurred (April 5-17, Bakun index CUI $=109 \mathrm{~m}^{3} \mathrm{~s}^{-1} 100 \mathrm{~m}^{-1}$ ), which gradually decreased toward the end of the cruising (April 25, CUI $=40 \mathrm{~m}^{3} \mathrm{~s}^{-1} 100 \mathrm{~m}^{-1}$ ), when satellite and in situ chlorophyll measurements were the lowest in Acapulco ( $<1.6 \mathrm{mg} \mathrm{m}^{-3}$, Supplementary Figure S1). This strong upwelling event, prior to the cruise, may explain the isotherms elevation in the Cabo Corrientes area and the displacement of the warmer water mass off the coast $\left(>25^{\circ} \mathrm{C}\right.$, stations St8 and St9), and the local shoaling of the Subtropical Subsurface Water (StSsW) (Fiedler and Talley, 2006), opposite to the oceanographic conditions occurring in Acapulco, where upwelling was weak at the time of sampling; coastal upwelling events have been previously documented for the coasts of Colima and Michoacán (Davies et al., 2015) and at the entrance of the Gulf of California and Cabo Corrientes (Pelayo-Martínez et al., 2017).

The second hypothesis assumes a combination of physiological characteristics, such as mobility, photosynthesis and cyst production, and environmental features (e.g., small-scale physical turbulence) which are found in the St 42 in Acapulco (Figures 4A,C). It has been reported that the distribution of toxic and non-toxic Alexandrium species, in other areas of the world, does not overlap (Anderson et al., 2012), which partially explains why only in some sites of the current study area, $A$. tamiyavanichii was detected.

TABLE 1 | Cell abundances of Alexandrium tamiyavanichii found in samples of the central Mexican Pacific by using qPCR assay.

\begin{tabular}{|c|c|c|c|}
\hline Station & Depth (m) & Cell density (cells $\mathrm{L}^{-1}$ ) & $\left(\right.$ cells $\mathrm{m}^{-3}$ ) \\
\hline \multirow[t]{5}{*}{7} & 5 & 0.47 & 475.83 \\
\hline & 12 & 25.18 & $25,179.8$ \\
\hline & 30 & 1.74 & $1,739.18$ \\
\hline & 70 & 0.062 & 61.89 \\
\hline & 150 & 0.041 & 40.61 \\
\hline \multirow[t]{5}{*}{8} & 5 & - & - \\
\hline & 11 & 0.11 & 110.36 \\
\hline & 18 & 0.046 & 45.78 \\
\hline & 45 & 0.04 & 39.54 \\
\hline & 75 & - & - \\
\hline \multirow[t]{5}{*}{22} & 5 & 19.22 & $19,218.1$ \\
\hline & 15 & - & - \\
\hline & 50 & - & - \\
\hline & 109 & - & - \\
\hline & 150 & - & - \\
\hline \multirow[t]{4}{*}{23} & 5 & 0.4 & 397.24 \\
\hline & 15 & 0.15 & 145.02 \\
\hline & 30 & - & - \\
\hline & 50 & - & - \\
\hline \multirow[t]{5}{*}{42} & 5 & 1.38 & 1380 \\
\hline & 10 & 0.232 & 232.16 \\
\hline & 18 & 0.035 & 35.35 \\
\hline & 24 & - & - \\
\hline & 28 & - & - \\
\hline
\end{tabular}

Stations, depths, and abundances (both in cells $\mathrm{L}^{-1}$ and cells $\mathrm{m}^{-3}$ ) are indicated. 

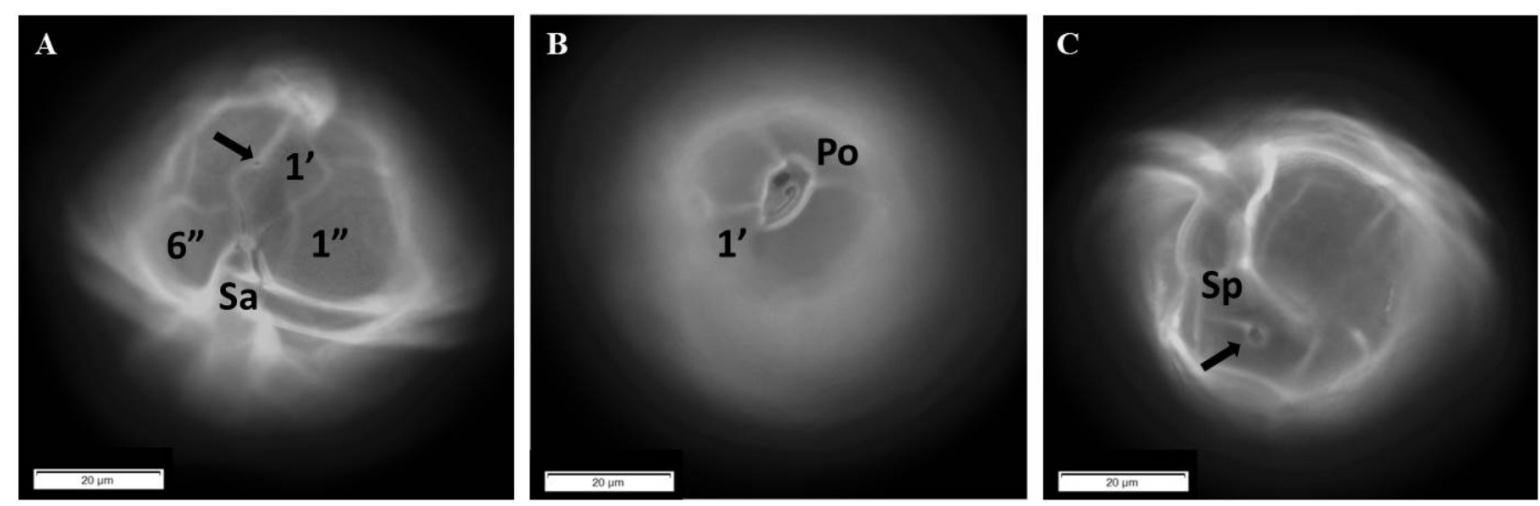

FIGURE 7 | Micrographs of Alexandrium tamiyavanichii in fluorescent microscopy showing some distinctive morphological characters. (A) Ventral view of a cell with the first apical plate $\left(1^{\prime}\right)$, the first and sixth precingular plate ( $1^{\prime \prime}$ and $6^{\prime \prime}$, respectively), and the anterior sulcal plate (Sa); the arrow points to the ventral pore. (B) Apical view showing the apical pore complex (Po) and the first apical plate (1'). (C) Antapical view with the posterior sulcal plate (Sp) and its large pore (arrowed).

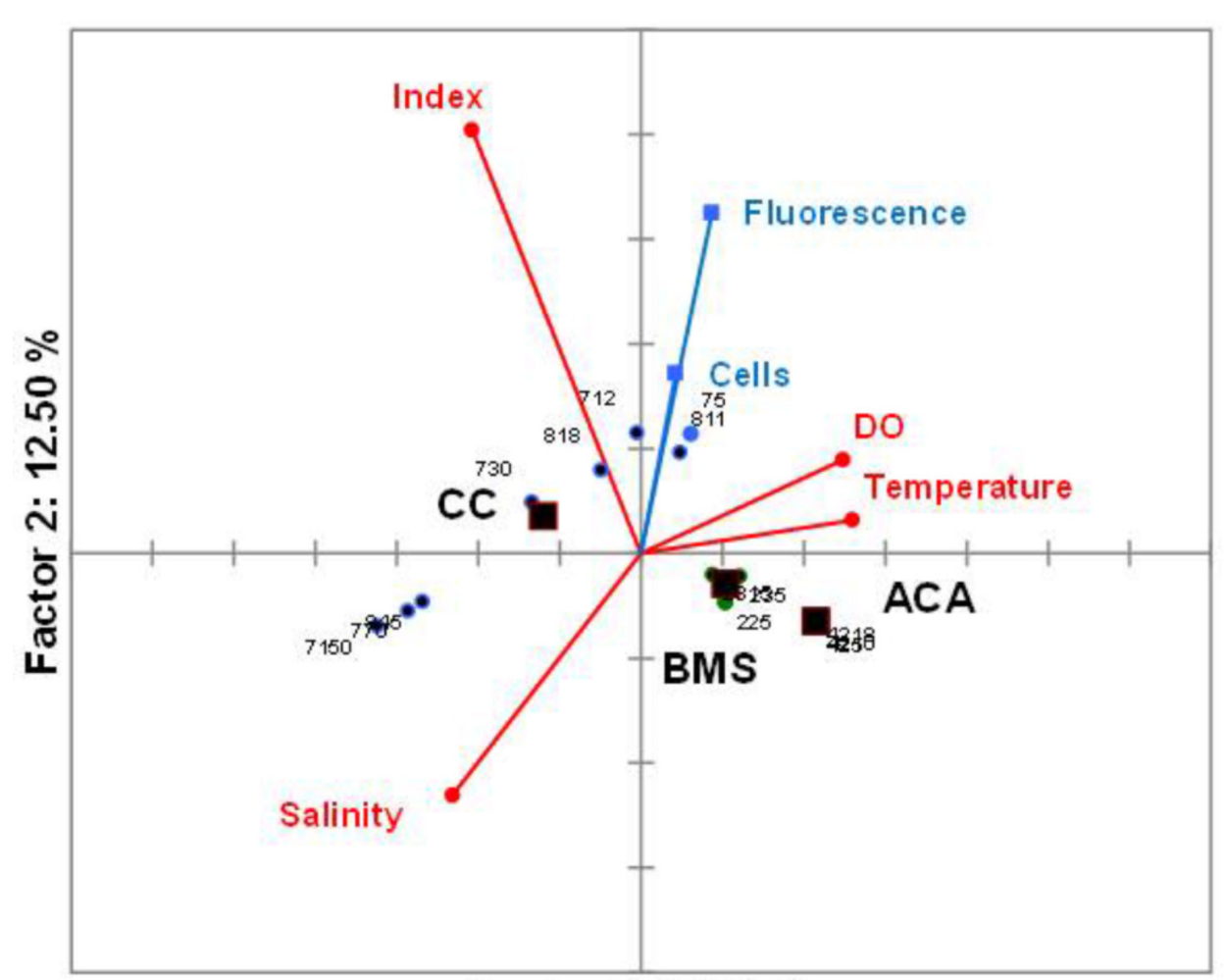

Factor 1: $81.64 \%$

FIGURE 8 | Principal component analysis (PCA) biplot (variables and samples) of the two first components from data of environmental and biotic variables of the central Mexican Pacific. Circles represent the samples and squares are the centroids for qualitative variables. CC, Cabo Corrientes; BMS, Manzanillo; and ACA, Acapulco transects.

Statistical analyses support the visual relationships (Figure 8) and coincidence between the fluorescence (chlorophyll $a$ ) highest values and the highest $A$. tamiyavanichii abundances in Cabo Corrientes (Figures 2B,D, 6A), and also the relationships with other environmental features such as temperature and dissolved oxygen, and induce to consider some preferences in environmental conditions the species may have: more stratified water column. At St 7, low abundances (40.61 cells $\mathrm{m}^{-3}$ ) of $A$. tamiyavanichii were yet detected, deeper into the water column, up to $150 \mathrm{~m}$ depth (Table $\mathbf{1}$ ).

The cell densities of A. tamiyavanichii found in this study are comparable (e.g., the same magnitude order) to numbers reported in a different area, with a similar irregular distribution (regarding horizontal and vertical distribution), following the 
same study method (Kon et al., 2015). Additionally, similar genetic structures are to be interpreted in populations found in various localities in waters of Malaysia and the populations studied in this work, for we pursued the same protocol.

It is plausible to consider that Alexandrium species may become an important component of the phytoplankton community in the Mexican Pacific, with the possibility of increasing their populations or expanding their geographic distribution, although until now there are not many reports of blooms or toxic episodes of the species of the genus (Hernández-Becerril et al., 2007). The use of molecular tools may improve our knowledge of the biodiversity and taxonomy of the phytoplankton in the Mexican Pacific, and aims the rapid and systematic reports of species involved in harmful events. The sensitivity of the method followed in this paper proved to be adequate for assessing the presence and distribution of $A$. tamiyavanichii.

\section{AUTHOR CONTRIBUTIONS}

DH-B designed the oceanographic cruise plan, obtained environmental data and samples, took samples for analysis, wrote and submitted the manuscript. WL made samples and data analysis. KSH made samples and data analysis and wrote part of the manuscript. FV-C performed the hydrographic and oceanographic information and statistical analysis. CPL supported samples analysis and edited part of

\section{REFERENCES}

Anderson, D. M., Alpermann, J. T., Cembella, A. D., Collos, Y., Masseret, E., and Montresor, M. (2012). The globally distributed genus Alexandrium: multifaceted roles in marine ecosystems and impacts on human health. Harmful Algae 14, 10-35. doi: 10.1016/j.hal.2011.10.012

Arvidsson, S., Kwasniewski, M., Riaño-Pachón, D. M., and Mueller-Roeber, B. (2008). QuantPrime - a flexible tool for reliable high-throughput primer design for quantitative PCR. BMC Bioinformatics 9:465. doi: 10.1186/1471-2105-9-465

Arya, M., Shergill, I. S., Williamson, M., Gommersall, L., Arya, N., and Patel, H. R. (2005). Basic principles of real-time quantitative PCR. Expert Rev. Mol. Diagn. 5, 209-219. doi: 10.1586/14737159.5.2.209

Balech, E. (1995). The Genus Alexandrium Halim (Dinoflagellata). Cork: Sherkin Island Marine Station.

Beppu, R., Nojima, K., Tsuruda, S., Gomez-Delan, G., Barte-Quilantang, M., Taniyama, S., et al. (2008). Occurrence of PSP-producing dinoflagellate Alexandrium tamiyavanichi in Bingo-Nada, the central coastal water of the Seto Inland Sea, Hiroshima Prefecture, Japan. Mar. Pollut. Bull. 56, 758-763. doi: 10.1016/j.marpolbul.2007.12.005

Bustin, S. A., Benes, V., Garson, J. A., Hellemans, J., Huggett, J., Kubista, M., et al. (2009). The MIQE Guidelines: minimum information for publication of quantitative real-time PCR experiments. Clin. Chem. 55, 611-622. doi: 10.1373/ clinchem.2008.112797

Cembella, A. D., and Taylor, F. J. R. (1986). Electrophoretic variability within the Protogonyaulax tamarensis/catenella species complex; pyridine linked dehydrogenases. Biochem. Syst. Ecol. 14, 311-321. doi: 10.1016/0305-1978(86) 90107-9

Davies, S. M., Sánchez-Velasco, L., Beier, E., Godínez, V. M., Barton, E. D., and Tamayo, A. (2015). Three-dimensional distribution of larval fish habitats in the shallow oxygen minimum zone in the eastern tropical Pacific Ocean off Mexico. Deep Sea Res. Part I 101, 118-129. doi: 10.1016/j.dsr.2015.04.003

Esqueda-Lara, K., and Hernández-Becerril, D. U. (2010). Dinoflagelados microplanctónicos marinos del Pacífico central de México (Isla Isabel, Nayarit the manuscript. PTL supported research stay and samples analysis.

\section{FUNDING}

Partial support for this study was provided by PAPIIT, DGAPA, UNAM (Project No. IN206516). Instituto de Ciencias del Mar y Limnología, Coordinación de la Investigación Científica (CIC, UNAM) approved and supported the use of the R/V "El Puma" (oceanographic cruise "MareaR IX," 19-30 April, 2017), and a short scientific stay of the senior author (DUH-B) to the Institute of Ocean and Earth Sciences, University of Malaya, Malaysia (June, 2017). Molecular work was supported by HiCOE IOES2014C to PTL.

\section{SUPPLEMENTARY MATERIAL}

The Supplementary Material for this article can be found online at: https://www.frontiersin.org/articles/10.3389/fmars. 2018.00366/full\#supplementary-material

FIGURE S1 | Mean surface chlorophyll in three zones of the central Mexican Pacific (Cabo Corrientes, Manzanillo and Acapulco), during April 19 (left) and April 27 (right). Data from: https://coastwatch.pfeg.noaa.gov/erddap/griddap/erd MH1chla8day.graph?chlorophyll[(2017-04-19T00:00:00Z)][(25.85417):(15.14583)] [(-110.4375):(-99.43749)]\&.draw=surface\&.vars=longitude $\% 7$ Clatitude $\% 7 C$ chlorophyll\&.colorBar=\%7C $\% 7 C \% 7 C \% 7 C \% 7 C \& . b g C o l o r=0 x f f c$ cccff. y costas de Jalisco y Colima). Mexico City: Universidad Nacional Autónoma de México, 206.

Fiedler, P. C., and Lavín, M. F. (2006). Introduction: a review of eastern tropical Pacific oceanography. Prog. Oceanogr. 69, 94-100. doi: 10.1016/j.pocean.2006. 03.006

Fiedler, P. C., and Talley, L. D. (2006). Hydrography of the eastern tropical Pacific: a review. Prog. Oceanogr. 69, 143-180. doi: 10.1016/j.pocean.2006. 03.008

Galluzzi, L., Penna, A., Bertozzini, E., Vila, M., Garcés, E., and Magnani, M. (2004). Development of a real-time PCR assay for rapid detection and quantification of Alexandrium minutum (a dinoflagellate). Appl. Environ. Microbiol. 70, 11991206. doi: 10.1128/AEM.70.2.1199-1206.2004

García, C., Bravo, M. C., Lagos, M., and Lagos, N. (2004). Paralytic shellfish poisoning: post-mortem analysis of tissue and body fluid samples from human victims in the Patagonia fjords. Toxicon 2, 149-158. doi: 10.1016/j.toxicon.2003. 11.018

Hashimoto, T., Matsuoka, S., Yoshimastsu, S., Miki, K., Nishibori, N., Nishio, S., et al. (2002). First paralytic shellfish poison (PSP) infestation of bivalves due to toxic dinoflagellate Alexandrium tamiyavanichii, in the southeast coasts of the Seto, Inland Sea, Japan. J. Food Hyg. Soc. Jpn. 43, 1-5. doi: 10.3358/shokueishi. 43.1

Hernández-Becerril, D. U., Alonso-Rodríguez, R., Álvarez-Góngora, C., BarónCampis, S. A., Ceballos-Corona, G., Herrera-Silveira, J., et al. (2007). Toxic and harmful marine phytoplankton and microalgae (HABs) in Mexican coasts. J. Env. Sci. Health Part A 42, 1349-1363. doi: 10.1080/10934520701480219

Hernández-Becerril, D. U., Barón-Campis, S. A., and Escobar-Morales, S. (2012). A new record of Azadinium spinosum (Dinoflagellata) from the tropical Mexican Pacific. Rev. Biol. Mar. Oceanogr. 47, 553-557. doi: 10.4067/S071819572012000300016

Hernández-Becerril, D. U., Rodríguez-Palacio, M. C., and Lozano-Ramírez, C. (2013). Morphology and life stages of the potentially pinnatoxin producing thecate dinoflagellate Vulcanodinium rugosum from the tropical Mexican Pacific. Bot. Mar. 56, 535-540. doi: 10.1515/bot-2013-0079 
Kessler, W. S. (2006). The circulation of the eastern tropical Pacific: a review. Prog Oceanogr. 69, 181-217. doi: 10.1016/j.pocean.2006.03.009

Kon, N. F., Teng, S. T., Hii, K. S., Yek, L. H., Aazani, M., Lim, H. C., et al. (2015). Spatial distribution of toxic Alexandrium tamiyavanichii (Dinophyceae) in the southeastern South China Sea-Sulu Sea: a molecular-based assessment using real-time quantitative PCR (qPCR) assay. Harmful Algae 50, 8-20. doi: $10.1016 /$ j.hal.2015.10.002

Lim, P.-T., Leaw, C.-P., and Ogata, T. (2007). Morphological variation of two Alexandrium species responsible for paralytic shellfish poisoning in Southeast Asia. Bot. Mar. 50, 14-21. doi: 10.1515/BOT.2007.003

López-Sandoval, D. C., Lara-Lara, J. R., Lavín, M. F., Álvarez-Borrego, S., and Gaxiola-Castro, G. (2009). Productividad primaria en el Pacífico oriental tropical adyacente a Cabo Corrientes, México. Ciencias Mar. 35, 169-182. doi: $10.7773 / \mathrm{cm} . v 35 \mathrm{i} 2.1530$

Mackenzie, L., de Salas, M., Adamson, J., and Beuzenberg, V. (2004). The dinoflagellate genus Alexandrium (Halim) in New Zealand coastal waters: comparative morphology, toxicity and molecular genetics. Harmful Algae 3, 71-92. doi: 10.1016/j.hal.2003.09.001

Menezes, M., Varela, D., de Oliveira Proença, L. A., da Silva, T. M., and Paredes, J. (2010). Identification of the toxic alga Alexandrium tamiyavanichii (Dinophyceae) from northeastern Brazil: a combined morphological and rDNA sequence (partial LSU and ITS) approach. J. Phycol. 46, 1239-1251. doi: 10. $1111 /$ j.1529-8817.2010.00918.x

Miller, P. E., and Scholin, C. A. (1998). Identification and enumeration of cultured and wild Pseudo-nitzschia (Bacillariophyta) using species-specific LSU rDNAtargeted fluorescent probes and filter-based whole cell hybridization. J. Phycol. 34, 371-382. doi: 10.1046/j.1529-8817.1998.340371.x

Mohammad-Noor, N., Adam, A., Lim, P. T., Leaw, C. P., Lau, W. L. S., Liow, G. R., et al. (2018). First report of paralytic shellfish poisoning (PSP) caused by Alexandrium tamiyavanichii in Kuantan Port, Pahang, East Coast of Malaysia. Phycol. Res. 66, 37-44. doi: 10.1111/pre.12205

Nagai, S. (2011). Development of a multiplex PCR assay for simultaneous detection of six Alexandrium species (Dinophyceae). J. Phycol. 47, 703-708. doi: 10.1111/ j.1529-8817.2011.00976.x

Nguyen, N.L., and Larsen, J. (2004). "Gonyaulacales," in Potentially Toxic Microalgae of Vietnamese Waters, Eds J. Larsen and N. L. Nguyen (Lund: Opera Botanica a Societate Botanica Lundensi), 140, 73-117.

Ogata, T., Pholpunthin, P., Fukuyo, Y., and Kodama, M. (1990). Occurrence of Alexandrium cohorticula in Japanese coastal waters. J. Appl. Phycol. 2, 351-356. doi: 10.1007/BF02180925

Okolodkov, Y. B., and Gárate-Lizárraga, I. (2006). An annotated checklist of dinoflagellates (Dinophyceae) from the Mexican Pacific. Acta Bot. Mex. 74, 1-154. doi: 10.21829/abm74.2006.1008

Paulmier, A., and Ruiz-Pino, D. (2009). Oxygen minimum zones (OMZs) in the modern ocean. Prog. Oceanogr. 80, 113-128. doi: 10.1016/j.pocean.2008.08.001

Pelayo-Martínez, G., Olivos-Ortiz, A., Franco-Gordo, C., Quijano-Scheggia, S., Gaviño-Rodríguez, J., Kono-Martínez, T., et al. (2017). Physical, chemical and zooplankton biomass variability (inshore-offshore) of Mexican Central Pacific during El Niño-La Niña 2010. Lat. Am. J. Aquat. Res. 45, 67-78. doi: 10.3856/ vol45-issue1-fulltext-7

Schlitzer, R. (2016). Ocean Data View. Available at: http://odv.awi.de/ [accessed May 29, 2018].

Scholin, C. A., Hallegraeff, G. M., and Anderson, D. M. (1995). Molecular evolution of the Alexandrium tamarense 'species complex' (Dinophyceae): dispersal in the North American and West Pacific regions. Phycologia 34, 472-485. doi: 10.2216/i0031-8884-34-6-472.1

Scholin, C. A., Herzog, M., Sogin, M., and Anderson, D. M. (1994). Identification of group- and strain-specific genetic markers for globally distributed Alexandrium (Dinophyceae). II. Sequence analysis of a fragment of the LSU rRNA gene. J. Phycol. 30, 999-1011. doi: 10.1111/j.0022-3646.1994.00999.x

Steidinger, K. A., and Moestrup, T. (1990). "The taxonomy of Gonyaulax, Pyrodium, Alexandrium, Gessnerium, Protogonyaulax and Goniodoma," in Toxic Marine Phytoplanton, Eds F. Graneli, B. Sundstrom, L. Edler, and D. M. Anderson (New York, NY: Elsevier), 522-523.

Ulloa, O., Canfield, D. E., Delong, E. F., Letelier, R. M., and Stewart, F. J. (2012). Microbial oceanography of anoxic oxygen minimum zones. Proc. Nat. Acad. Sci. U.S.A. 109, 15996-16003. doi: 10.1073/pnas.1205009109

Usup, G., Leaw, C.-P., Asmat, A., and Lim, P.-T. (2002a). Alexandrium (Dinophyceae) species in Malaysian waters. Harmful Algae 1, 265-275.

Usup, G., Pin, L. C., Ahmad, A., and Teen, L. P. (2002b). Phylogenetic relationship of Alexandrium tamayavanichii (Dinophyceae) to other Alexandrium species based on ribosomal RNA gene sequences. Harmful Algae 1, 59-68. doi: 10.1016/ S1568-9883(02)00003-3

Willett, C. S., Leben, R., and Lavín, M. F. (2006). Eddies and tropical instability waves in the eastern tropical Pacific: a review. Prog. Oceanogr. 69, 218-238. doi: 10.1016/j.pocean.2006.03.010

Ye, J., Coulouris, G., Zaretskaya, I., Cutcutache, I., Rozen, S., and Madden, T. L. (2012). Primer-BLAST: a tool to design target-specific primers for polymerase chain reaction. BMC Bioinformatics 13:134. doi: 10.1186/1471-2105-13-134

Zamudio, L., Hurlburt, H. E., Metzger, E. J., and Tilburg, C. E. (2007). Tropical wave-induced oceanic eddies at Cabo Corrientes and the Maria Islands, Mexico. J. Geophys. Res. 112, 1-17. doi: 10.1029/2006JC004018

Conflict of Interest Statement: The authors declare that the research was conducted in the absence of any commercial or financial relationships that could be construed as a potential conflict of interest.

Copyright $\odot 2018$ Hernández-Becerril, Lau, Hii, Leaw, Varona-Cordero and Lim. This is an open-access article distributed under the terms of the Creative Commons Attribution License (CC BY). The use, distribution or reproduction in other forums is permitted, provided the original author(s) and the copyright owner(s) are credited and that the original publication in this journal is cited, in accordance with accepted academic practice. No use, distribution or reproduction is permitted which does not comply with these terms. 